\title{
Angielski po daltońsku, czyli plan daltoński na lekcjach języka angielskiego
}

\section{Teaching English in the Dalton Way, i. e. the Dalton Plan in English Lessons}

\section{SŁOWA KLUCZE ABSTRAKT}

plan daltoński, Mimo że pedagogika planu daltońskiego stworzona została przez

Helen Parkhurst, Helen Parkhurst sto lat temu, to nadal jest użyteczna i chętnie wyjęzyk angielski, korzystywana w pracy z dziećmi zarówno w wieku przedszkolnym, nauczanie, uczenie się, edukacja jak i wczesnoszkolnym. W niniejszym artykule zaprezentowano sposoby wykorzystania elementów planu daltońskiego na lekcjach jęwczesnoszkolna zyka angielskiego. W jego pierwszej części przedstawiony jest zarys historyczny powstania planu daltońskiego, krótkie przybliżenie postaci twórczyni oraz główne założenia koncepcji. Następnie opisano rozwój idei na świecie i w Polsce oraz przybliżono współczesną realizację filarów planu daltońskiego. W drugiej części artykułu podano praktyczne rozwiązania, możliwe do wykorzystania na lekcjach języka angielskiego, zgodne z założeniami koncepcji Helen Parkhurst. Założeniem autorki jest zainspirowanie nauczycieli języków obcych do poszukiwania nowych metod i zachęcenie ich do poszerzenia swojego warsztatu o narzędzia rozwijające u dzieci samodzielność, odpowiedzialność, współpracę oraz refleksję. Praca zgodnie z założeniami tej koncepcji pozwala na indywidualizację pracy ucznia oraz rozwój zarówno językowy, jak i społeczny, co zmierza do realizacji nadrzędnego celu, jakim jest wspieranie wszechstronnego rozwoju dziecka. 


\section{KEYWORDS ABSTRACT}

Dalton Plan, Helen

Parkhurst, English lesson, teaching, learning, early school education
The Dalton Plan's pedagogy was established by Helen Parkhurst 100 years ago, but it is still valued and commonly applied in preschool and early school education. In this article, I intend to present different ways of implementing the Dalton Plan into teaching English at these stages. First, I will discuss the history of the Dalton Plan, and then I shall describe its founder and outline the main assumptions of the concept. Next, I will present how the Dalton Plan has developed worldwide, in particular in Poland, and I will discuss the current application of the Dalton Plan in the school environment. In the second part, I will present Helen Parkhurst's practical teaching strategies which can be effectively used in teaching English to children. I intend this article to be not only an inspiration for teachers teaching different foreign languages but also as an encouragement for practitioners to reflect on their work and perhaps expand their practice with new teaching strategies that would promote independence, responsibility, cooperation and reflection. Applying the Dalton Plan in everyday teaching allows teachers to personalise children's learning and supports the development of children's linguistic and social skills, which, in turn, facilitates the main objective of education, i. e. the child's comprehensive development.

\section{Plan daltoński - rys historyczny}

Plan daltoński to koncepcja pracy z dzieckiem stworzona przez Amerykankę Helen Parkhurst, która jak wielu ówcześnie żyjących twórców teorii edukacji (np. Maria Montessori czy John Dewey) poszukiwała nowych rozwiązań w pracy z dziećmi. Jej własne doświadczenia szkolne oraz fakt, iż przez wiele lat jako dziecko uczestniczyła w kursach dla nauczycieli, którzy dopiero uczyli się zawodu, spowodowały, że - będąc małą dziewczynką - obiecała sobie, iż zostanie nauczycielką. „Później Parkhurst wspominała, że jako dziecko, uczęszczając na sesje w Instytucie dla Nauczycieli, doszła do wniosku, że ma obowiązek zostać nauczycielem w celu udowodnienia, że dzieci nie są naprawdę złe, jedynie niezrozumiane" (Lager 1983: 63). Helen Parkhurst zdecydowanie krytykowała tradycyjną szkołę. Przez kilka lat współpracowała z Marią Montessori, wiele jej założeń dotyczących edukacji dziecka jest zbieżnych z poglądami Włoszki. Na przykład uważała, że organizacja przestrzeni w klasie nie wspiera procesu uczenia się, przykręcone do podłogi ławki uniemożliwiają tworzenie zespołów i naukę poprzez współpracę, zmiana aktywności co 45 minut przeszkadza w skupieniu się nad wykonywanym zadaniem oraz nie uwzględnia indywidualnego podejścia do ucznia. Była orędowniczką tzw. nowej szkoły, postulowała, by uczniowie: 
(...) wykazywali zainteresowanie swoją własną pracą, byli samodzielni, czuli się swobodnie, badali i podejmowali próby, dyskutowali, byli radośni z własnej pracy, starali się przykładnie pracować oraz być pomocnymi w całej klasie, pomagali w szczególności osobom słabszym, przyjmowali pomoc od zdolniejszych, czynili w szkole tyle, ile tylko potrafią (Śliwerski 2011: 15).

Dlatego też, tworząc swój model edukacyjny, Helen Parkhurst chciała osiągnąć równowagę pomiędzy talentami każdego dziecka a potrzebami społeczeństwa. Autorka w szczególności skupiła się na dostosowaniu programu do potrzeb, zainteresowań i umiejętności indywidualnych uczniów, promowaniu niezależności, jak i zaufania do innych, polepszeniu zdolności interpersonalnych uczniów oraz poczuciu odpowiedzialności w stosunku do wspólnoty.

Całą swoją koncepcję Helen Parkhurst skupiła wokół takich wartości jak wolność, odpowiedzialność i współpraca. Wolność rozumiała jako zaprzeczenie swawoli czy braku posłuszeństwa, definiowała ją w następujący sposób:

(...) wolność pracowania bez przerwy nad przedmiotem, w którym (uczeń) się pogrąży, bo gdy pracuje z zainteresowaniem, to jest daleko bystrzejszy, czujniejszy i zdolniejszy do pokonania wszelkich trudności, jakie napotkać może w ciągu swej pracy. (...) O ile uczniowi nie pozwoli się przyswajać sobie wiedzy z szybkością, jaka jemu jest właściwa, to nie nauczy się nigdy niczego gruntownie. Wolność polega na braniu właściwego sobie tempa. Praca w tempie narzuconym jest niewolą (Parkhurst 1928: 17).

Wolność, według twórczyni, to zgoda na „zanurzenie się” w poznawanych treściach poprzez dostosowanie odpowiedniego tempa oraz samodzielny wybór realizowanych treści. By tak się stało, konieczne było przesunięcie akcentu z pracy nauczyciela na ucznia, z nauczania na uczenie się. Nauczyciel miał przekazać odpowiedzialność za proces uczenia się uczniom, usunąć się na drugi plan. „Głównym jego zadaniem powinno być przygotowanie pomyślnych warunków dla pracy uczniów, dyskretne kierowanie nią przez udzielanie rady i pomocy, wreszcie kontrolowanie i ocenianie jej wyników" (Nawroczyński 2017: 169).

Kolejnym celem było nauczenie dzieci współdziałania każdego z każdym, młodszego ze starszym, współpracy w mniejszych i większych zespołach.

Prawdziwe współżycie społeczne jest więcej niż kontaktem - jest współdziałaniem i wzajemnym oddziaływaniem na siebie. (...) Daltoński Plan Laboratoryjny wytwarza takie warunki, z których chcąc korzystać, uczeń mimowolnie działa jako członek zorganizowanej społeczności. Jest on przyjmowany lub też odpychany przez tę społeczność zależnie od tego, czy jego działanie lub zachowanie się jest społecznym, czy też nie (Parkhurst 1928: 18). 
Helen Parkhurst podkreślała znaczenie współpracy pomiędzy uczniami i nauczycielami. Zwłaszcza ten drugi wymiar miał, według niej, ogromne znaczenie, bez którego nie osiągnie się zamierzonych efektów. Bogdan Nawroczyński wyjaśnia: „Chodzi jej o to, aby nauczyciele nie odgradzali się w szkole od uczniów sztuczną powagą, ale z nimi współpracowali i współżyli, jak rodzice współżyją ze swoimi dziećmi, a starsi towarzysze z młodszymi” (Nawroczyński 2017: 169).

Trzecim celem było uczynienie uczniów odpowiedzialnymi za proces uczenia się. By tak się stało, musieli znać cel i kryteria oceny wykonania zadania.

Gdy dziecko ponosi odpowiedzialność za wybór, umysł jego działa jak potężny mikroskop, dostrzegający i ważący każdą stronę zadania, które musi pokonać, by osiągnąć powodzenie. (...) Stosując Daltoński Plan Laboratoryjny, stawia się dziecku zadanie wprost przed oczy, wskazując cel, jaki ma być osiągnięty. Następnie wolno mu wziąć się do pracy w taki sposób, jaki samo uważa dla siebie za najodpowiedniejszy, oraz we właściwym sobie tempie. Poczucie odpowiedzialności za rezultaty rozwinie w nim nie tylko utajone siły intelektualne, ale także sąd samodzielny i charakter (Parkhurst 1928: 19).

„Źle jest, gdy posuwają się ślepo za nauczycielem, nie rozumiejąc, dokąd ich prowadzi” (Nawroczyński 2017: 170). Te trzy główne zasady mocno się przenikały i uzupełniały, dając całościowy obraz koncepcji.

\section{Innowacyjne rozwiazania Helen Parkhurst}

Helen Parkhurst miała zaledwie 19 lat, kiedy podjęła swoją pierwszą pracę w wiejskiej szkole jako wychowawczyni, pod jej opieką było 40 uczniów w wieku od 6 do 16 lat. Było to ogromne wyzwanie organizacyjne oraz dydaktyczne, ponadto jej najstarsi uczniowie byli od niej niewiele młodsi. Pracę rozpoczęła od przeorganizowania sali szkolnej, wynosząc z niej wszystkie ławki, a następnie przygotowując stanowiska z zadaniami dla dzieci w każdym kącie sali, na środku aranżując miejsce do czytania. Dzięki temu uczniowie mogli w mniejszych grupkach pracować na przygotowanych stanowiskach, dostosowując czas i miejsce pracy do swoich potrzeb. Twórczyni przez kilkanaście kolejnych lat doskonaliła swój plan, sprawdzała go i modernizowała. Ostateczną wersję wprowadziła w szkole w Dalton (Massachusetts, USA), gdzie każda sala lekcyjna była tzw. laboratorium, czyli odpowiednio przygotowaną przestrzenią, dostosowaną do nauczanego tam przedmiotu, gdzie uczniowie samodzielnie planowali pracę, a nauczyciele wspierali ich w rozwijaniu wolności, odpowiedzialności i współpracy. W kolejnych latach nastąpiło rozpowszechnienie planu daltońskiego na świecie. Powstawały szkoły w Anglii, Chinach oraz Holandii. 
W Polsce w latach dwudziestych publikowano artykuły na ten temat. O zaletach systemu daltońskiego pisał m.in. pedagog Rudolf Taubenszlag na łamach „Ruchu Pedagogicznego" w 1929 roku. Wśród atutów wymieniał samokształcenie, zamiłowanie do książek, pracę samodzielną, pracę indywidualną, poznanie własnej osobowości, rozwijanie zainteresowań, wewnętrznego przymusu i karności czy koncentrację nad zadaniami i ich zróżnicowanie. Również Jadwiga Młodowska dostrzegała wiele walorów tej koncepcji i w 1926 roku jako pierwsza zastosowała plan daltoński w Państwowym Seminarium Nauczycielskim w Chełmie. Prawdziwy rozkwit koncepcji nastąpił po roku 2009, kiedy to Roel Röhner i Hanse Wenke (wieloletni nauczyciele daltońscy, propagatorzy tej idei w Europie i nie tylko, konsultanci Dalton International), podczas konferencji zorganizowanej w Łodzi przez OMEP - Światową Organizację Wychowania Przedszkolnego - zaprezentowali współczesną, holenderską recepcję planu. Po tym wydarzeniu powstało Polskie Stowarzyszenie Dalton, które rozpoczęło propagowanie koncepcji w kraju oraz proces certyfikacji placówek gotowych do jej realizacji. Aktualnie w Polsce jest ponad 50 certyfikowanych daltońskich szkół i przedszkoli oraz blisko 50 placówek będących w procesie certyfikacji (https://dalton.org.pl/ placowki-czlonkowskie/, dostęp: 25.11.2019 r.).

\section{Współczesna realizacja planu daltońskiego}

Polskie placówki pracujące zgodnie z założeniami pedagogiki planu daltońskiego opierają swoje działania na czterech filarach: samodzielności, odpowiedzialności, współpracy i refleksji.

Wcześniejsza „wolność” została zastąpiona „samodzielnością”, by właściwie ją definiować i nie kojarzyć ze swawolą. Wyodrębniono dodatkowy filar - refleksję, która nie była wyróżniona przez twórczynię metody, ale wielokrotnie o niej pisała i podkreślała jej znaczenie w procesie uczenia się. W myśl założeń Helen Parkhurst w każdej placówce zasady te dostosowywane są do odpowiedniej grupy dzieci, do ich potrzeb oraz zainteresowań.

Filozofia Helen Parkhurst za całkowicie normalne i słuszne uznaje regularne testowanie swoich własnych zasad i sprawdzanie, czy są one wciąż zgodne z duchem czasu. Plan daltoński to nie system, to sposób na życie. (...) Helen Parkhurst widzi własne koncepcje nie jako sztywne schematy. Można je dopasować do praktyki działania każdej szkoły, w taki sposób, by nie naruszać ich fundamentów. Elastyczność koncepcji daltońskiej odwołuje się do zdolności twórczych ucznia i nauczyciela. A wszystko to ma na celu stworzenie szkoły, w której uczeń rzeczywiście może się uczyć (Röhner i Wenke 2011: 21). 
Sposoby realizacji filarów planu daltońskiego różnią się pomiędzy placówkami, jednakże interpretacja zasad jest porównywalna. Samodzielność rozumiana jest przede wszystkim jako autonomiczne dochodzenie do wiedzy, bez ciągłego nadzorowania przez nauczyciela, swobodne poszukiwanie rozwiązań, szeroko pojęta niezależność w myśleniu i działaniu, a także funkcjonowanie w grupie oraz samoobsługa. Odpowiedzialność to przesunięcie akcentu z aktywności nauczyciela na ucznia, przekazanie uczniom dominującej roli. Odpowiedzialność za proces uczenia się, dochodzenia do wiedzy, a nie jedynie za efekt - wynik. Współpraca rozumiana jest jako wspólna nauka i zabawa, podział zadań i obowiązków, odpowiedzialność za grupę oraz za przestrzeń, w której przebywają. To współpraca każdego z każdym, szacunek dla odmienności, umiejętność osiągania kompromisów. Zaś refleksja to umiejętność spojrzenia na własną pracę przed wykonaniem zadania i po jego zakończeniu, skupienie na celu, znajomość kolejnych mniejszych kroków, by osiągnąć zaplanowany cel oraz ocena własnych osiągnięć. Praca zgodna z założeniami tej koncepcji inspiruje uczniów do kreatywnego oraz zaangażowanego działania. Taka zmiana jest dostępna dla każdego twórczego nauczyciela.

\section{Przedmiot i cel podjętej refleksji}

Przedmiotem refleksji uczyniłam nauczanie oraz uczenie się języka angielskiego z wykorzystaniem założeń planu daltońskiego. Pytanie, wokół którego skoncentruję moje poszukiwania naukowe, brzmi: jak można wykorzystywać narzędzia zgodne z założeniami planu daltońskiego na lekcjach języka angielskiego?

\section{Język obcy w edukacji wczesnoszkolnej}

Proces nauczania języków obcych w edukacji elementarnej powinien przebiegać w sposób spójny z treściami podstawy programowej kształcenia ogólnego dla edukacji wczesnoszkolnej z zakresu edukacji polonistycznej, matematycznej, społecznej, plastycznej, technicznej, informatycznej i muzycznej. Podstawa programowa nakłada na nauczycieli języka obowiązek zapoznania się z całą podstawą programową kształcenia ogólnego dla szkoły podstawowej z zakresu edukacji wczesnoszkolnej i na bieżąco śledzenia jej realizacji, tak aby edukacja z zakresu języka obcego nowożytnego wspierała podstawowe treści nauczania i była przez nie wspierana, przede wszystkim w zakresie kluczowych pojęć i umiejętności, takich jak np. liczenie, pisanie. Metody i techniki pracy są zbieżne, skoncentrowane na rozwoju wybranych umiejętności w ramach 
sprawności językowych, zmierzają do realizacji nadrzędnego celu, jakim jest wspieranie wszechstronnego rozwoju ucznia.

\section{Wykorzystanie elementów planu daltońskiego w nauczaniu języka angielskiego w klasach I-III. Rozwiązania praktyczne}

Pracując w klasie, zgodnie z założeniami edukacji daltońskiej, skupiamy działania uczniów na rozwijaniu samodzielności, odpowiedzialności, współpracy oraz refleksji. Wiele z narzędzi, które wykorzystują nauczyciele daltońscy, można przenieść na grunt nauczania języka obcego. Modelowym rozwiązaniem byłoby wprowadzenie zasad pedagogiki planu daltońskiego zarówno podczas zajęć zintegrowanych, jak również na języku angielskim, aczkolwiek nawet jednotorowe rozwiązanie będzie korzystne dla uczniów.

Plan daltoński, jak już wcześniej wspominałam, nie jest metodą, a zatem nie ma gotowych scenariuszy do poprowadzenia lekcji daltońskiej. Nie ma również pomocy daltońskich ${ }^{1}$, a jedynie narzędzia, które mogą wspierać pracę nauczyciela i uczniów. Poniżej prezentuję przykładowe sposoby pracy na lekcjach języka angielskiego, zgodne z założeniami pedagogiki planu daltońskiego.

Rozwijanie umiejętności językowych poprzez samodzielne działanie uczniów można realizować, przygotowując krótkie instrukcje, których celem jest pomoc uczniom w swobodnym funkcjonowaniu w przestrzeni klasy oraz samodzielne uczenie się. Instrukcje są odpowiedzią nauczycieli na pytania najczęściej zadawane przez uczniów. Mogą one dotyczyć spraw organizacyjnych, dydaktycznych lub wychowawczych. Jest to lista kroków do wykonania w konkretnej sytuacji, np. jak na ilustracji 1:

\footnotetext{
1 Pisząc o pomocach daltońskich, mam na myśli pomoce opracowane i opatentowane przez Helen Parkhurst. Są pewne narzędzia charakterystyczne dla tej koncepcji, ale używanie ich podczas zajęć nie daje gwarancji przeprowadzenia lekcji zgodnych z założeniami planu daltońskiego. O ile Maria Montessori opracowała wiele pomocy dydaktycznych z dokładną instrukcją, jak ich używać, o tyle Helen Parkhurst takich materiałów nie pozostawiła.
} 
Il. 1. Instrukcja „Before English lesson prepare...”

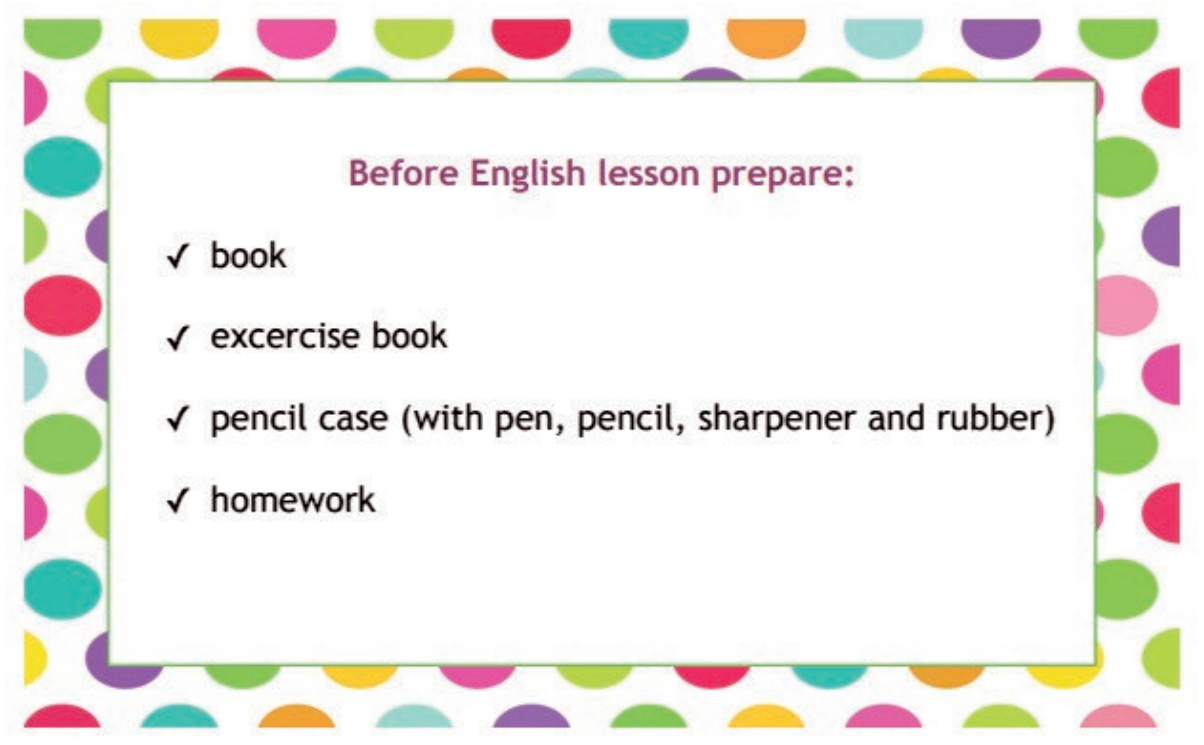

Źródło: opracowanie własne.

Dzięki takiej liście kontrolnej uczniowie samodzielnie organizują swoją przestrzeń przed kolejną lekcją, nie potrzebują wskazówek i kontroli nauczyciela, działają indywidualnie, w zorganizowany sposób. Jeśli dzieci nie potrafią jeszcze samodzielnie czytać, wówczas każde słowo łączymy z obrazkiem, pamiętając, aby przy nim zawsze umieszczony był zapis słowny, dzięki czemu uczniowie mimowolnie go analizują i zapamiętują. Innym przykładem może być instrukcja, co zrobić po skończeniu zadania:

1. Przeczytaj jeszcze raz polecenie i swoją odpowiedź. Oceń, czy wykonałeś zadanie zgodnie z poleceniem.

2. Sprawdź, czy wykonałeś wszystkie zadania.

3. Upewnij się, czy każde zdanie zaczyna się wielką literą i kończy kropką.

4. Jeśli skończyłeś pracę przed czasem, wybierz anglojęzyczną książkę lub pomoc i pracuj.

5. Odłóż pracę we wskazane miejsce.

Uczniowie, korzystając z przedstawionej instrukcji, dzięki ponownemu przeczytaniu polecenia i własnego rozwiązania, bardzo często samodzielnie dostrzegają i korygują błędy. Niezwykle użyteczna jest również wizualizacja, podpisana krótkim zdaniem, przedstawiająca, co ma zrobić uczeń, kiedy nie wie, jak rozwiązać zadanie. Może ona brzmieć tak: 
1. Przeczytaj jeszcze raz polecenie.

2. Przypomnij sobie, co tłumaczył nauczyciel.

3. Szukaj rozwiązań w materiałach.

4. Poproś o pomoc osobę, z którą współpracujesz.

5. Poproś ekspertów o pomoc.

6. Poproś nauczyciela o pomoc.

Il. 2. Instrukcja „Co zrobić, kiedy nie wiem, jak wykonać zadanie?”, autorka: A. Juljańska

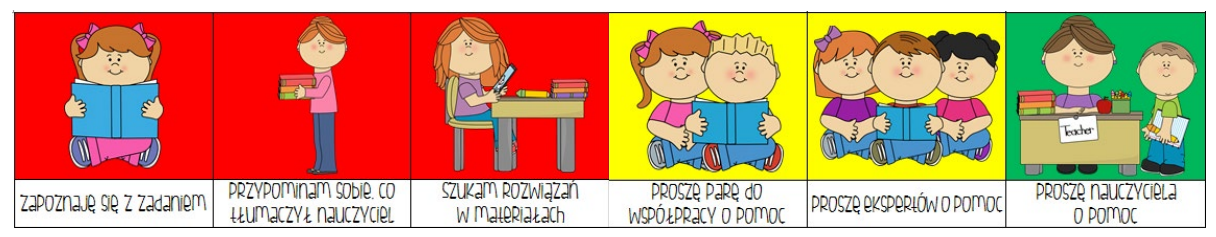

Każdą instrukcję, którą wprowadzamy, na początku omawiamy, następnie eksponujemy w wyznaczonym miejscu w klasie, tak by każdy miał do niej swobodny dostęp. Ważne, aby uczniowie wiedzieli, jak z niej korzystać i czemu służy. Nauczyciel, przygotowując instrukcję, powinien pamiętać, że każde nowe narzędzie wprowadzone do klasy musi mieć konkretny cel, rozwijać realne umiejętności dzieci. Zasady, o których powinniśmy pamiętać, tworząc instrukcje, to czytelność i przejrzystość; całość powinna zawierać się w 4-6 krokach, ma pozwalać na samodzielną pracę i niezależne funkcjonowanie w grupie.

Rozwijanie umiejętności językowych poprzez współpracę możemy realizować, wykorzystując tablicę „I am good at...”. W widocznym miejscu w klasie umieszczamy napis „I am good at...” i wypisujemy umiejętności, takie jak: writing, reading, listening, speaking, making puzzles, making laugh etc. 
Il. 3. Narzędzie wspierające „I am good at...”

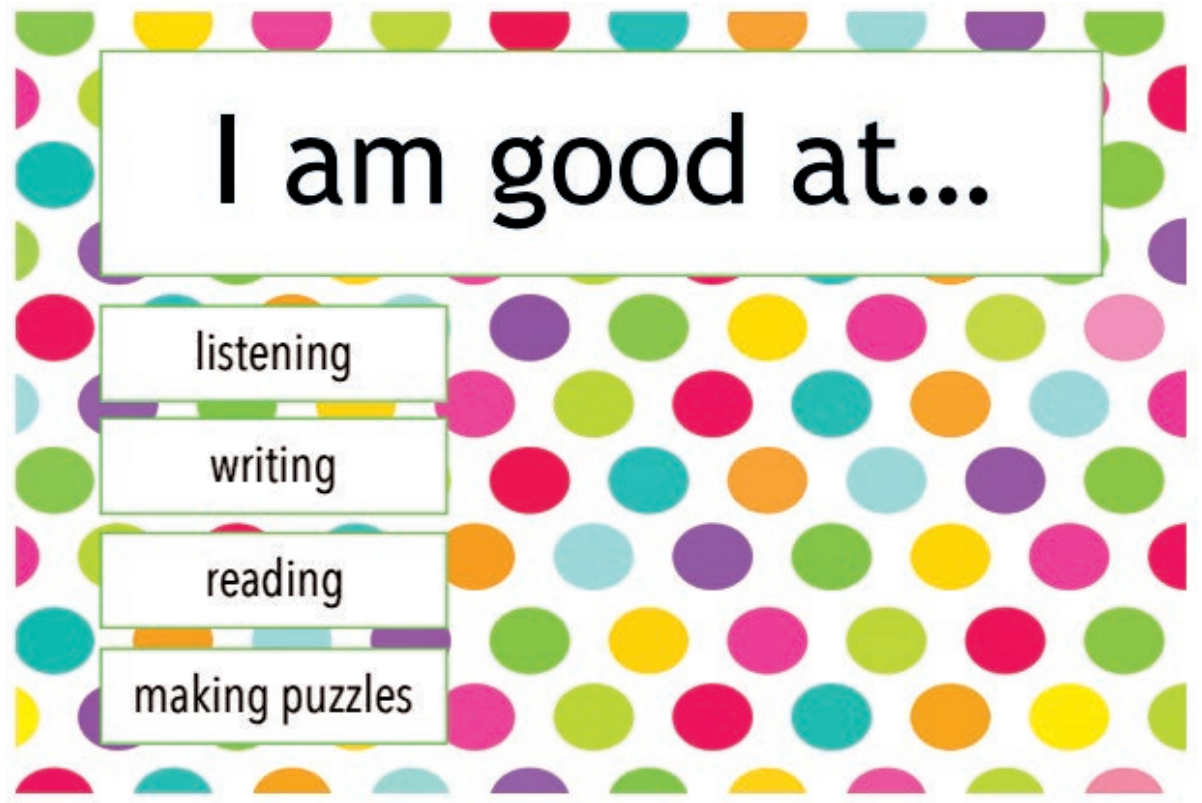

Źródło: opracowanie własne.

Mogą być one zaczerpnięte z podstawy programowej. Dodatkowo warto poszerzyć listę o umiejętności społeczne, tak by każdy odnalazł kategorię, w której jest dobry. Obok każdego hasła eksponujemy emblemat z imieniem dziecka, które daną umiejętność już posiada. Jeśli podczas lekcji dzieci pracują samodzielnie, a mają z czymś problem, wówczas spoglądają na tablicę i wiedzą, do kogo mogą się udać z prośbą o pomoc. W wielu sytuacjach nauczyciel nie jest potrzebny, to rówieśnik może wesprzeć i wytłumaczyć. Przygotowując taką tablicę, bardzo ważne jest, aby każdemu dziecku przypisana była jedna umiejętność. To zapewni wzrost poczucia własnej wartości i kompetencji, zaspokoi potrzebę bycia potrzebnym, pomocnym i wyjątkowym.

Dobrym przykładem na rozwijanie odpowiedzialności u uczniów jest ich samodzielne planowanie swojej pracy. Tutaj również plan daltoński daje nam pewne możliwości, oto przykład. Raz w tygodniu nauczyciel przygotowuje treści, które uczniowie będą realizowali przez najbliższe pięć dni. Na wykonanie zadań uczniowie mogą mieć wyznaczony czas (np. 20 min.) lub całą lekcję, decyzja należy do nauczyciela (często zależy od liczby godzin języka angielskiego w tygodniu). W karcie do planowania ten czas oznaczony jest symbolem IW (individual work). Ważne jest, że treści zawarte w karcie nie są zadaniami dodatkowymi, ale obowiązkowymi dla każdego. Na początku 
nauczyciel omawia cele na najbliższy tydzień, tak by uczniowie wiedzieli, do czego dążą i po czym poznają, że dany temat zrealizowali. Następnie prezentuje wszystkie przygotowane materiały. Idealnie byłoby, gdyby każde zadanie było opracowane na trzech poziomach (podstawowy, średni, zaawansowany), tak by dzieci samodzielnie mogły zdecydować, który poziom wybiorą. Po omówieniu wszystkich zadań przez nauczyciela każdy indywidualnie planuje, które zadanie, na jakim poziomie i którego dnia wykona. Dalej wpisuje, czy i ewentualnie jakie dodatkowe materiały będą mu potrzebne do realizacji zadań, by mógł je sobie przygotować, aby w czasie pracy nie rozpraszał się poszukiwaniem odpowiednich danych. Po wykonaniu zaznacza, kiedy realnie je wykonał, i oddaje całość nauczycielowi do sprawdzenia. Największą wartością takiej pracy jest rozwijanie samodzielności, odpowiedzialności, współpracy, refleksji oraz wzrost motywacji. Uczniowie samodzielnie decydują, co i kiedy wykonają, dzięki temu czują się za swoją pracę odpowiedzialni i chętniej się jej podejmują.

Poniżej prezentuję przykładową kartę do planowania. Zadania, które w niej zamieściłam, ściśle wiążą się z podstawą programową dla klas I-III.

Karta zawiera przykładowe zadania, część z nich jest do wykonania w podręczniku, inne na karcie pracy, a gra jest materiałem ogólnodostępnym w klasie.

To, co uczeń planuje na karcie, zaznacza również na ogólnej tablicy umieszczonej w sali lekcyjnej. Dzięki temu nauczyciel na bieżąco może kontrolować postępy w pracy uczniów. Całkowicie uzupełniona tablica jest początkiem refleksji, jaką podejmują uczniowie po zakończonej pracy, jest również świetnym materiałem do przemyśleń dla nauczyciela. Ostatnim elementem jest rozmowa na temat wykonanych zadań. Jest to czas, w którym uczniowie dzielą się swoimi osiągnięciami, mówią, czego się nauczyli, z czym sprawnie sobie radzą, nad czym muszą popracować, a do czego potrzebują pomocy kolegi lub nauczyciela. Wypowiadają się na temat treści zaproponowanych zadań: czy były ciekawe, dość interesujące, czy czekają na inne, jak przebiegała praca z osobą do współpracy (czy była bardzo dobra, dobra, czy mogło być lepiej), a także oceniają swoją postawę do pracy (czy była chętna, dobra, czy może negatywna). Wszystkie te informacje są bazą dla nauczyciela do tworzenia kolejnych zadań, które będą odpowiadały na potrzeby i zainteresowania uczniów. 
November 11th-15th

\section{Class 3}

\begin{tabular}{|c|c|c|c|c|c|}
\hline & MONDAY & TUESDAY & WEDNESDAY & THURSDAY & FRIDAY \\
\hline IW & $30 \mathrm{~min}$ & $20 \mathrm{~min}$ & $30 \mathrm{~min}$ & $35 \mathrm{~min}$ & $20 \mathrm{~min}$ \\
\hline topic & \multicolumn{5}{|c|}{$\begin{array}{l}\text { - Czytam ze zrozumieniem } \\
\text { - Utrwalam nazwy członków rodziny } \\
\text { - Utwalam nazwy części ciała } \\
\text { - Słucham ze zrozumieniem }\end{array}$} \\
\hline
\end{tabular}

\begin{tabular}{|c|c|c|c|c|c|c|}
\hline & 占吊 & tasks (what to do) & ए回同 & $(i-i)$ & Q & 二ः \\
\hline$\sum$ & $\bullet$ & $\begin{array}{l}\text { Wysłuchaj nagrana przez nauczyciela instrukcję "Mój dom". Wykonaj } \\
\text { budowlę z klocków. Sprawdź wykonanie z kartą samokontroli. }\end{array}$ & CD player, blocks & $20 \mathrm{~min}$ & & \\
\hline$\overline{\underline{\underline{z}}}$ & $\bullet \bullet$ & $\begin{array}{l}\text { Wysłuchaj nagrana przez nauczyciela instrukcję "Mój dom". Wykonaj } \\
\text { budowlę z klocków. Sprawdź wykonanie z karta samokontroli. Następnie } \\
\text { samodzielnie zaprojektuj dom i nagraj instrukcję dla kolegów z klasy. }\end{array}$ & $\begin{array}{l}\text { CD player, blocks, } \\
\text { dictaphone }\end{array}$ & $30 \mathrm{~min}$ & & \\
\hline$\sum$ & • & $\begin{array}{l}\text { Przeczytaj komiks „My family" i zaznacz prawidłowe odpowiedzi na } \\
\text { pytania do tekstu. }\end{array}$ & class book, pencil & $20 \mathrm{~min}$ & & \\
\hline 픔 & $\bullet \bullet$ & $\begin{array}{l}\text { Przeczytaj komiks „My family” i odpowiedz na pytania. Odpowiedzi } \\
\text { zanotuj w zeszycie. }\end{array}$ & $\begin{array}{l}\text { class book, pencil,, } \\
\text { notebook }\end{array}$ & $20 \mathrm{~min}$ & & \\
\hline$\stackrel{\Xi}{E}$ & $\bullet$ & Ułóż zdania z rozsypanki wyrazowej. Przepisz podane zdania do zeszytu. & $\begin{array}{l}\text { worksheet, scissors, } \\
\text { glue }\end{array}$ & $15 \mathrm{~min}$ & & \\
\hline$\leq$ & $\bullet \bullet$ & Opisz jednego członka Twojej rodziny. Opis powinien zawierać 5 zdań. & Notebook, pencil & $18 \mathrm{~min}$ & & \\
\hline 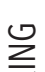 & $\bullet$ & $\begin{array}{l}\text { Spośród wypisanych pytań wybierz te, które dotyczq tematu rodzina. } \\
\text { Wytnij je, wklej do zeszyłu a następnie przeprowadź mini wywiad z para } \\
\text { do współpracy. }\end{array}$ & $\begin{array}{l}\text { class book, activity } \\
\text { book pencil }\end{array}$ & $20 \mathrm{~min}$ & & \\
\hline ص & $\bullet \bullet$ & $\begin{array}{l}\text { Wymyśl } 7 \text { pytań tak by dowiedzieć się jak najwięcej o rodzinie Twojego } \\
\text { kolegi z tawki. Zapisz pytania, poproś nauczyciela o sprawdzenie, a } \\
\text { następnie przeprowadź z kolegq mini wywiad. }\end{array}$ & $\begin{array}{l}\text { class book, activity } \\
\text { book pencil }\end{array}$ & $25 \mathrm{~min}$ & & \\
\hline$\sum_{\Xi}^{\amalg}$ & & $\begin{array}{l}\text { Zagraj w Dobble Family. Wymieniajcie członków rodziny jedynie po } \\
\text { angielsku! }\end{array}$ & Dobble Family & $10 \mathrm{~min}$ & & ${ }_{0}^{4} 3$ \\
\hline
\end{tabular}

\footnotetext{
Źródło: opracowanie własne.
} 


\section{Podsumowanie}

Kiedy mówimy o nauczaniu języków obcych w klasach I-III, myślimy o edukacji pozostającej w zgodzie z holistycznymi zasadami postrzegania świata. Celem takiego nauczania jest wyposażenie uczniów w narzędzia pozwalające rozwiązywać zadania nie tylko szkolne, ale przede wszystkim życiowe. Ważna jest nie tylko wiedza, ale także umiejętności i rozwój osobowościowy. Wykorzystanie elementów planu daltońskiego na lekcjach języka angielskiego daje możliwości tworzenia propozycji, dzięki którym rozwijamy nie tylko umiejętności językowe dzieci, ale także podkreślamy aspekt wychowawczy poprzez rozwijanie samodzielności, odpowiedzialności, współpracy i refleksji. Taki model pracy nakierowany jest na aktywność uczniów, komunikację, współpracę oraz samodzielne rozwiązywanie problemów. Praca na lekcjach języka obcego zgodnie z założeniami koncepcji daje również możliwości intensyfikacji procesu indywidualizacji pracy z uczniem.

Cele nauczania języka angielskiego na poziomie początkowym to m.in. rozwijanie w uczniach poczucia własnej wartości oraz wiary we własne możliwości językowe, doskonalenie się i przyjmowanie odpowiedzialności, a w szczególności rozwijanie stopniowej obserwacji i analizy własnych osiagnięć w nauce oraz samooceny, wdrażanie do współpracy w grupie, w małych zespołach zadaniowych, w parach, nauka organizowania pracy własnej, projektowania działania i racjonalnego gospodarowania czasem (Pamuła 2006: 55).

Wszystkie powyższe cele zawierają się w filarach planu daltońskiego, dlatego, realizując założenia koncepcji Helen Parkhurst, naturalnie je osiągamy, dodatkowo stymulując harmonijny rozwój uczniów i pozwalając nauczycielowi na prowadzenie twórczych i ciekawych zajęć.

\section{Bibliografia}

Lager D. (1983). Helen Parkhurst and the Dalton Plan: the Life and Work of an American Educator, praca niepublikowana, The University of Connecticut.

Pamuła M. (2006). Metodyka nauczania jezyków obcych $w$ kształceniu zintegrowanym, Warszawa: Fraszka Edukacyjna.

Parkhurst H. (1928). Wyksztatcenie wedtug planu daltońskiego, Lwów-Warszawa: Książnica. Atlas.

Röhner R., Wenke H. (2011). Pedagogika planu daltońskiego, tłum. E. Zygmunt, Łódź: Wydawnictwo Sor-Man.

Taubenszlag R. (1929). System daltoński. Rekonstrukcja planu - jego zalety i wady - wskazania, „Ruch Pedagogiczny” nr 2, 3, 4. 
Śliwerski B. (2011). Recepcja planu daltońskiego Helen Parkhurst w Polsce, [w:] R. Röhner, H. Wenke, Pedagogika planu daltońskiego, tłum. E. Zygmunt, Łódź: Wydawnictwo Sor-Man, s. 15.

Śliwerski B., Walancik M. (red.). (2017). Wybór tekstów Profesora Bogdana Nawroczyńskiego, Kraków: Impuls.

https://dalton.org.pl/placowki-czlonkowskie/ (dostęp: 25.11.2019).

\section{ADRES DO KORESPONDENCJI}

Marta Kwella

Uniwersytet Łódzki

Katedra Pedagogiki Wieku Dziecięcego

e-mail: marta.kwella@uni.lodz.pl 